\title{
Monthly Variations of the Nitrogen Isotope of Ammonium in Wet Deposition in a Tropical City of South China
}

\author{
Fajin Chen ${ }^{1,2 *}$ Qibin Lao ${ }^{1,2,3}$, Zhiyang $\mathrm{Li}^{4}$, Peiwang Bian ${ }^{1,2}$, Qingmei Zhu ${ }^{1,2}$, Chunqing Chen ${ }^{1,2}$, \\ Zhiguang Song ${ }^{1}$
}

\author{
${ }^{1}$ Guangdong Province Key Laboratory for Coastal Ocean Variation and Disaster Prediction, Guangdong Ocean \\ University, Zhanjiang 524088, China \\ ${ }^{2}$ College of Ocean and Meteorology, Guangdong Ocean University, Zhanjiang 524088, China \\ ${ }^{3}$ Marine Environmental Monitoring Centre of Beihai, State Oceanic Administration, Beihai 266031, China \\ ${ }^{4}$ Guangdong AIB Polytechnic College, Guangzhou 551507, China
}

\begin{abstract}
Nitrogen isotope of ammonium $\left(\delta^{15} \mathrm{~N}_{-} \mathrm{NH}_{4}{ }^{+}\right)$in the wet deposition in Zhanjiang, a typical tropical city in the southernmost region of mainland China, were analyzed from October 2015 to November 2018 in order to examine the monthly variations and identify the sources of ammonia. The $\mathrm{NH}_{4}^{+}$exhibited higher concentrations during the dry season than the wet one, whereas the $\delta^{15} \mathrm{~N}_{-} \mathrm{NH}_{4}{ }^{+}$displayed the opposite trend of higher values during the wet season. Comparing the $\delta^{15} \mathrm{~N}-\mathrm{NH}{ }_{4}^{+}$and the weather parameters (e.g., rainfall, temperature and duration of sunshine), we found the change in the duration of sunshine to be primarily responsible for the observed temporal isotopic variation. During the wet season, a significantly longer duration increased the opportunities for photooxidation and enhanced the formation of free radicals, which resulted in larger amounts of sulfur dioxide $\left(\mathrm{SO}_{2}\right)$ and nitrogen oxide $\left(\mathrm{NO}_{x}\right)$ being transformed into sulfuric acid $\left(\mathrm{H}_{2} \mathrm{SO}_{4}\right)$ and $\mathrm{HNO}_{3}$. This process accelerated the unidirectional conversion of $\mathrm{NH}_{3}$ into $\left(\mathrm{NH}_{4}\right)_{2} \mathrm{SO}_{4}$ - and $\mathrm{NH}_{4} \mathrm{NO}_{3}$-enriched ${ }^{14} \mathrm{~N}$ particles, which can be deposited by aerosols, and led to ${ }^{15} \mathrm{~N}$-enriched residual $\mathrm{NH}_{3}$ being present in the atmosphere; this $\mathrm{NH}_{3}$ was then scavenged by precipitation and released as $\mathrm{NH}_{4}{ }^{+}$during rainfall. By contrast, less isotopic fractionation occurred during the shorter sunshine duration of the dry season, suggesting that $\delta^{15}{\mathrm{~N}-\mathrm{NH}_{4}}^{+}$in the precipitation should be similar to those of $\mathrm{NH}_{3}$ in the atmosphere and can therefore be applied in source apportionment. A Bayesian isotope mixing model demonstrated that volatilization contributed less (18 $\pm 21 \%$ and $19 \pm 20 \%$ from animal waste and fertilizer, respectively) than combustion (28 $\pm 26 \%, 24 \pm 26 \%$ and $11 \pm 5 \%$ from coal combustion, vehicle exhaust and biomass burning) to the concentration of $\mathrm{NH}_{4}{ }^{+}$in Zhanjiang's precipitation.
\end{abstract}

Keywords: Ammonium; $\delta^{15} \mathrm{~N}$; Wet deposition; Bayesian isotope mixing model; Tropical area.

\section{INTRODUCTION}

Nitrogen $(\mathrm{N})$ is an important element in the ecosystem (Galloway et al., 2008; Xiao et al., 2012). Recently, excessive anthropogenic $\mathrm{N}$ emissions have greatly increased $\mathrm{N}$ deposition, particularly from the 1980 s through the early $21^{\text {st }}$ century (Galloway et al., 2004; Fang et al., 2010; Xu et al., 2017; Biswas et al., 2019). Increasing $\mathrm{N}$ deposition has induced harmful effects on the ecosystem and atmospheric environment (Galloway et al., 2004; Fang et al., 2010; Jiang et al., 2019). Ammonium $\left(\mathrm{NH}_{4}{ }^{+}\right)$is an important form of $\mathrm{N}$

\footnotetext{
* Corresponding author.

Tel.: +86-759-2396037

E-mail address: fjchen04@163.com
}

deposition (Galloway et al., 2008; Liu et al., 2013) and mainly originates from fossil fuel consumption, volatilized sources (e.g., animal wastes and fertilizer) and biomass burning (Huang et al., 2012; Kang et al., 2016; Zheng et al., 2018; Peng et al., 2019). Previous studies indicate that the increase in ammonia $\left(\mathrm{NH}_{3}\right)$ emissions from 1980 s to first few years of the $21^{\text {st }}$ century in China was mostly from livestock waste (49\%) and synthetic fertilizer applications $(37 \%)$, and remain stable or slightly decreased over the past few years (Kang et al., 2016). However, the ammonia concentration in atmosphere is still high, and has caused serious environmental pollution (Xiao et al., 2012; Liu et al., 2013; Liu et al., 2017; Zheng et al., 2018).

Nitrogen isotope in ammonium $\left(\delta^{15} \mathrm{~N}_{-} \mathrm{NH}_{4}^{+}\right)$in precipitation provide a valuable geochemical tracing technique called fingerprint identification (Xie et al., 2008; Jia and Chen, 2010; Xiao et al., 2012; Altieri et al., 2015; Liu et al., 2017), 
which is powerful to trace the sources of $\mathrm{NH}_{4}{ }^{+}$and the reaction process of deposited $\mathrm{NH}_{4}{ }^{+}$in ecosystems (Jia and Chen, 2010; Altieri et al., 2016; Liu et al., 2017). For example, $\delta^{15} \mathrm{~N}$ in wet deposition has been used successfully to identify $\mathrm{NH}_{4}^{+}$sources in Guangzhou (Jia and Chen, 2010); Guiyang (Xiao et al., 2012; Liu et al., 2017; Zheng et al., 2018); the Yangtze River Delta region (Zhao et al., 2009); Chengdu (Li et al., 2007); Pretoria, South Africa (Heaton, 1987); and Niigata Platin, Japan (Fukuzaki and Hayasaka, 2009). In addition, based on the stable isotope mixing model, Liu et al. (2017) found that volatilization sources (animal waste [22\%] and fertilizer [22\%]) contributed less pollution than ammonia derived from combustion sources (vehicle exhaust [19\%], coal combustions [19\%] and biomass burning [17\%]) in Guiyang, China. Moreover, $\delta^{15} \mathrm{~N}^{-\mathrm{NH}_{4}}{ }^{+}$in wet deposition can be modified by weather conditions (Jia and Chen, 2010; Xiao et al., 2012). For example, washout processes preferentially incorporate heavy isotopes $\left({ }^{15} \mathrm{~N}\right)$, which leads to heavier $\delta^{15} \mathrm{~N}_{-} \mathrm{NH}_{4}{ }^{+}$in precipitation (Xiao et al., 2012). Sunshine duration also influences $\delta^{15} \mathrm{~N}_{-} \mathrm{NH}_{4}{ }^{+}$in precipitation because free radicals and photooxidation can produce sulfur dioxide $\left(\mathrm{SO}_{2}\right)$ and nitrogen oxide $\left(\mathrm{NO}_{x}\right)$ to acidic matter $\left(\mathrm{H}_{2} \mathrm{SO}_{4}\right.$ and $\left.\mathrm{HNO}_{3}\right)$ in the atmosphere, which accelerates the transition of $\mathrm{NH}_{3}$ (gas phase) into $\left(\mathrm{NH}_{4}\right)_{2} \mathrm{SO}_{4}$ and $\mathrm{NH}_{4} \mathrm{NO}_{3}$ (particulate phase) by unidirectional reactions for isotopically enriched ${ }^{14} \mathrm{~N}$ (Xiao et al., 2012). This process results in ${ }^{15} \mathrm{~N}$-enriched residual $\mathrm{NH}_{3}\left(\mathrm{NH}_{4}^{+}\right)$in wet deposition. However, these studies mainly focus on the middle and high latitudes. In contrast, little is known about ammonium sources and the composition of nitrogen isotopes in precipitation in low latitude areas, which exhibit significantly different weather conditions relative to the middle and high latitude areas.

In this study, a time series investigation of $\mathrm{NH}_{4}^{+}$ concentrations and $\delta^{15} \mathrm{~N}-\mathrm{NH}_{4}{ }^{+}$in wet deposition was conducted from October 2015 to November 2018 in Zhanjiang, a typical tropical area in the southernmost region of mainland China. We strived to identify the main factors that control seasonal variations of $\delta^{15} \mathrm{~N}-\mathrm{NH}_{4}{ }^{+}$and to elucidate the different sources of $\mathrm{NH}_{4}{ }^{+}$in wet deposition in such tropical areas.

\section{MATERIALS AND METHODS}

\section{Sampling Station and Sample Collection}

Rainwater samples were collected in Zhanjiang (20.00$21.58^{\circ} \mathrm{N}, 109.52-110.92^{\circ} \mathrm{E}$ ), which is located in western Guangdong Province in South China near the northern extent of the South China Sea (Fig. 1). As a tropical city, Zhanjiang has a tropical monsoon climate with relatively high annual mean temperatures $\left(23.0^{\circ} \mathrm{C}\right)$ and high annual mean rainfall (1689 mm; China Meteorological Data Service Center, http://data.cma.cn/). The annual duration of sunshine in Zhanjiang is very long ( 2000 hours) due to its low latitude (China Meteorological Data Service Center, $\mathrm{http}: / /$ data.cma.cn/n). The transitional months from the winter monsoon to the summer monsoon usually occur in spring, with rainfall sharply increasing in May, and subsequently decreasing after October (Fig. 2(e)). Thus, the wet season is defined as taking place from May to October, and the dry season is defined as taking place from November to April.

From October 2015 to November 2018, rainwater samples were collected for each precipitation event on the roof of a building at Guangdong Ocean University in Zhanjiang. A dry polyethylene bucket $(80 \mathrm{~cm}$ in diameter) cleaned with acid was used to collect rainwater. Rain events with rainfall less than $0.5 \mathrm{~mm}$ were considered invalid and not collected. After collection, the rainwater samples were filtered through glass fiber filters (GF/Fs; $47 \mathrm{~mm}$ in diameter; Whatman) and into polyethylene bottles, which were previously soaked with $30 \%$ (v/v) $\mathrm{HCl}$ for $24 \mathrm{~h}$ and cleaned with ultrapure water and dried in the laboratory. Samples were stored frozen at $-20^{\circ} \mathrm{C}$, and they were analyzed soon after being melted. Similar procedures have been conducted in numerous studies (e.g., Jia and Chen, 2010; Liu et al., 2017; Xiao et al., 2012; Zheng et al., 2018). During the period from October 2015 to November 2018, 315 rainwater samples were collected. The rainwater samples collected each month were proportionally mixed into a large sample according to the rainfall amount that month, thus composing a representative sample of wet deposition for the entire month. The results of the analysis of $\mathrm{NH}_{4}{ }^{+}$concentrations in the mixed samples are monthly weighted averages.

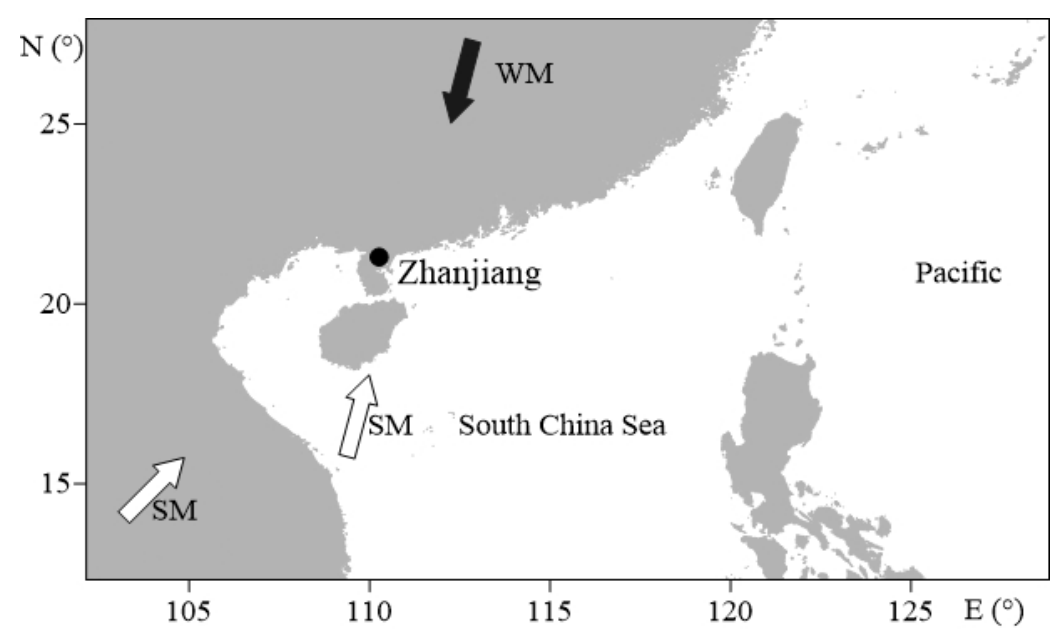

Fig. 1. The sampling site in Zhanjiang, South China (black dot). WM: winter monsoon; SM: summer monsoon. 


\section{Sample Analysis}

$\mathrm{NH}_{4}{ }^{+}$concentrations were determined by spectrophotometry after treatment with Nessler's reagent, and the detection limit was lower than $0.1 \mathrm{mg} \mathrm{L}^{-1}$. For the isotopic analysis, $\mathrm{NH}_{4}^{+}$ was first quantitatively oxidized to $\mathrm{NO}_{2}^{-}$by hypobromite $\left(\mathrm{BrO}^{-}\right)$at a $\mathrm{pH}$ of 12 . Excess $\mathrm{BrO}^{-}$was consumed by sodium arsenite. $\mathrm{NO}_{2}^{-}$was further reduced to $\mathrm{N}_{2} \mathrm{O}$ with $1: 1$ sodium azide in an acetic acid buffer (Lin et al., 2007). Subsequently, $\mathrm{N}_{2} \mathrm{O}$ was separated, purified and analyzed for $\delta^{15} \mathrm{~N}$ with a GasBench II-MAT 253. The international standards, IAEAN1, USGS 25 and USGS 26, were used for $\delta^{15} \mathrm{~N}$ calibration. The analysis deviation for the standard was $<0.2 \%$ for $\delta^{15} \mathrm{~N}$. The reproducibility of duplicate analyses was $<0.3 \%$ for $\delta^{15} \mathrm{~N}$ (average $\pm 0.1 \%$ )

\section{Data Sources and Calculations}

Monthly atmospheric $\mathrm{SO}_{2}$ data was from historical air quality data in Zhanjiang (China air quality online monitoring and analysis platform, https://www.aqistudy.cn/). The sunshine duration, temperature, humidity, wind direction and wind speed were obtained from the China Meteorological Data Sharing Service System (China Meteorological Data Service Center, http://data.cma.cn/).

\section{Backward Trajectories}

To reveal possible sources of pollutants, the web version of the model Hybrid Single-Particle Lagrangian Integrated Trajectory (HYSPLIT) was used to calculate three days (72 h) of back trajectories (BTs; https://ready.arl.noaa.gov/ HYSPLIT traj.php). The BTs were generated from the sampling location at a height of $500 \mathrm{~m}$ above sea level. A trajectory time of three days $(72 \mathrm{~h})$ was chosen due to the short residence time of $\mathrm{NH}_{4}{ }^{+}$in the atmosphere (less than three days) (Xiao and Liu, 2002).

\section{Stable Isotope Analysis in R (SIAR) Mixing Model}

To calculate the proportional contribution of potential $\mathrm{NH}_{4}{ }^{+}$sources in Zhanjiang, a Bayesian stable isotope mixing model was conducted using the SIAR package. In this model, a Bayesian framework was used to calculate the probability distribution for the proportion of each source to the mixture. The following equation was used:

$$
\begin{aligned}
& X_{i j}=\sum_{k=1}^{k} P_{k}\left(S_{j k}+c_{j k}\right)+\varepsilon_{i j} \\
& S_{j k} \sim N\left(\mu_{j k}, \omega_{j k}^{2}\right) \\
& c_{j k} \sim N\left(\lambda_{j k}, \tau_{j k}^{2}\right) \\
& \varepsilon_{j k} \sim N\left(0, \sigma_{j}^{2}\right)
\end{aligned}
$$

where $X_{i j}$ denotes the isotopic values $\left(j=1, \delta^{15} \mathrm{~N}-\mathrm{NH}_{4}{ }^{+}\right)$of the sample $i(i=1,2,3, \ldots, N) ; S_{j k}$ denotes the isotopic value $j$ of the source $k(k=1,2,3, \ldots, K)$, which is normally distributed with the average $\mu_{j k}$ and the standard deviation $\omega_{j k} ; P_{k}$ denotes the contribution of source $k$, which is determined by the SIAR model; $c_{j k}$ denotes the fractionation factor for $j$ in source $k$, where $c_{j k}$ is normally distributed with the average $\lambda_{j k}$ and the standard deviation $\tau_{j k}$; and $\varepsilon_{j k}$ denotes the residual error of the additional unquantified variation between individual samples, which are normally distributed with average 0 and standard deviation $\sigma_{j}$. This model was used by previous studies, therefore a more detailed model description can be found in Moore and Semmens (2010), Xue et al. (2012) and Zhang et al. (2018).

\section{RESULTS}

Monthly rainfall, $\mathrm{NH}_{4}{ }^{+}$concentration, $\delta^{15} \mathrm{~N}-\mathrm{NH}_{4}{ }^{+}$values, $\mathrm{SO}_{2}$ and $\mathrm{NO}_{2}$ concentration, sunshine duration and temperature, recorded from October 2015 to November 2018, are summarized in Fig. 2. The lack of $\mathrm{NH}_{4}{ }^{+}$concentrations and $\delta^{15} \mathrm{~N}_{-} \mathrm{NH}_{4}{ }^{+}$during February 16, December 16, January 17 and December 17 is because very little $(<0.5 \mathrm{~mm})$ or no rainfall occurred during these periods. The average $\mathrm{NH}_{4}{ }^{+}$ concentration ranged from 0.43 to $3.11 \mathrm{mg} \mathrm{L}^{-1}$ during the sampling period, with an average of $0.82 \mathrm{mg} \mathrm{L}^{-1}$. Considering only the annual averages, we find that there is no significant trend in the variation of $\mathrm{NH}_{4}^{+}$concentration. The annual mean $\mathrm{NH}_{4}{ }^{+}$concentration are $1.04 \mathrm{mg} \mathrm{L}^{-1}, 0.65 \mathrm{mg} \mathrm{L}^{-1}$ and $0.78 \mathrm{mg} \mathrm{L}^{-1}$ in 2016, 2017 and 2018, respectively, suggesting that the concentrations of $\mathrm{NH}_{4}{ }^{+}$slightly decreased after 2016 . Compared with the wet seasons, higher concentrations of $\mathrm{NH}_{4}{ }^{+}$were found during the dry seasons (Fig. 2(e)). According to the precipitation and annual mean $\mathrm{NH}_{4}{ }^{+}$concentration during the three study years, wet $\mathrm{NH}_{4}{ }^{+}-\mathrm{N}$ deposition in 2016, 2017 and 2018 in Zhanjiang was $22.7 \mathrm{~kg} \mathrm{~N} \mathrm{ha}^{-2}$, $13.3 \mathrm{~kg} \mathrm{~N} \mathrm{ha}^{-2}$ and $19.0 \mathrm{~kg} \mathrm{~N}^{-2}$, respectively. The $\delta^{15} \mathrm{~N}_{-} \mathrm{NH}_{4}{ }^{+}$ ranged from -18.0 to $-3.9 \%$, with an average of $-9.6 \%$. The

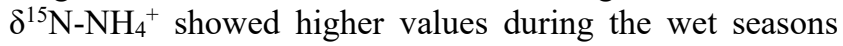
relative to lower values during the dry seasons, which is consistent with variations in rainfall, sunshine duration and temperature, but contradictory to variations in $\mathrm{SO}_{2}$ and $\mathrm{NH}_{4}{ }^{+}$ concentrations (Fig. 2). This pattern in variation of $\delta^{15} \mathrm{~N}_{-} \mathrm{NH}_{4}^{+}$ in Zhanjiang is different from other areas, such as Guizhou in western China (Xiao et al., 2012), which exhibited higher values in winter and lower values in summer.

\section{DISCUSSION}

\section{Concentration of $\mathrm{NH}_{4}^{+}$in Precipitation}

In this study, the $\mathrm{NH}_{4}^{+}$concentration in rainwater in Zhanjiang is lower than in Guangzhou (1.10 $\mathrm{mg} \mathrm{L}^{-1}$; Jia and Chen, 2010), Guiyang (1.98 $\mathrm{mg} \mathrm{L}^{-1}$; Xiao et al., 2012) and in the Yangtze River Delta region $\left(1.20 \mathrm{mg} \mathrm{L}^{-1}\right.$; Zhao et al., 2009), but higher than the subtropical forest ecosystems in remote areas of South China (ranged from 0.02 to $0.05 \mathrm{mg} \mathrm{L}^{-1}$; Chen and Mulder, 2007). The wet deposition fluxes in Zhanjiang (18.3 $\mathrm{kg} \mathrm{N} \mathrm{ha}^{-2}$ in three year average) are slightly lower than that reported values observed in Guangzhou (27.4 $\mathrm{kg} \mathrm{N} \mathrm{ha}^{-2}$; Jia and Chen, 2010) and Guiyang (23.2 $\mathrm{kg} \mathrm{N} \mathrm{ha}^{-2}$; Xiao et al., 2012), and higher than that in the Yangtze River Delta region $\left(14.9 \mathrm{~kg} \mathrm{~N} \mathrm{ha}^{-2}\right.$; Zhao et al., 2009), indicating significant $\mathrm{N}$ pollution in the city. In areas with intensive human activities, anthropogenic sources (such as industrial activities and agricultural productivity) 


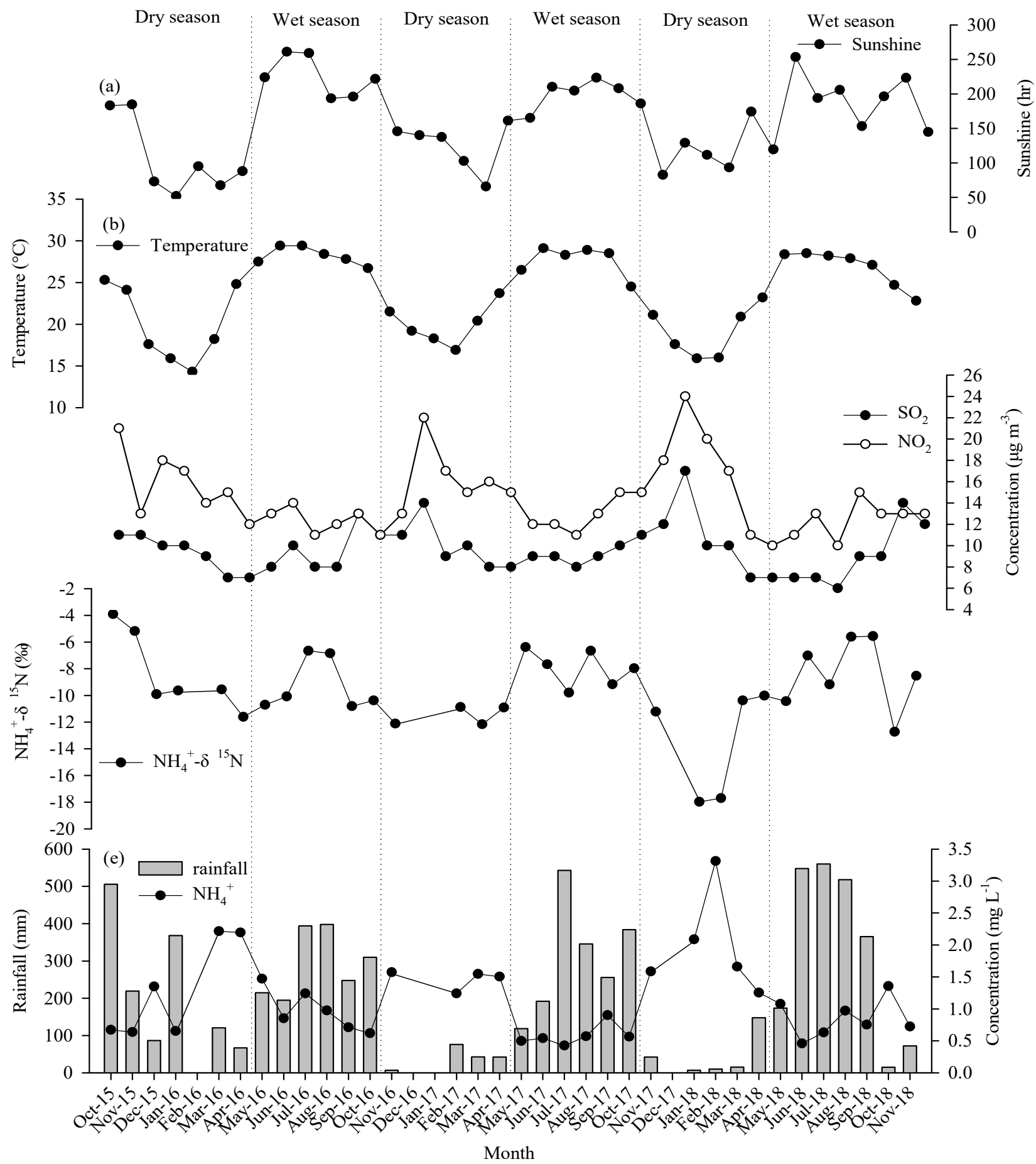

Fig. 2. Comparisons of $\delta^{15} \mathrm{~N}-\mathrm{NH}_{4}{ }^{+}$with $\mathrm{NH}_{4}{ }^{+}$concentration and atmospheric parameters in Zhanjiang. Monthly (a) sunshine duration, (b) temperature, (c) $\mathrm{SO}_{2}$ and $\mathrm{NO}_{2}$ concentration, (d) $\delta^{15} \mathrm{~N}-\mathrm{NH}_{4}{ }^{+}$and (e) rainfall and $\mathrm{NH}_{4}^{+}$concentration. The lack of $\mathrm{NH}_{4}{ }^{+}$concentrations and $\delta^{15} \mathrm{~N}_{-} \mathrm{NH}_{4}{ }^{+}$in Feb 16, Dec 16, Jan 17 and Dec 17 is because very little $(<0.5 \mathrm{~mm})$ or no rainfall occurred during these periods.

may provide the most important contribution to $\mathrm{NH}_{4}{ }^{+}$in wet deposition. In addition, sources of $\mathrm{NH}_{4}^{+}$include natural sources, such as human and animal excrement and fertilizer, which are closely associated with agricultural activities (Jia and Chen, 2010; Peng et al., 2019; Zhao et al., 2009). The annual averages of $\mathrm{NH}_{4}^{+}$concentration are $1.04 \mathrm{mg} \mathrm{L}^{-1}$, $0.65 \mathrm{mg} \mathrm{L}^{-1}$ and $0.78 \mathrm{mg} \mathrm{L}^{-1}$ in 2016, 2017 and 2018, respectively, suggesting that the $\mathrm{NH}_{4}^{+}$pollution is in an unstable level. This interannual variation might be related with the weather parameters, which will be monitored in the future to clarify this issue. Due to the seasonal distribution pattern, higher $\mathrm{NH}_{4}{ }^{+}$concentrations occur in the dry seasons (November-April) and lower concentrations occur in the wet seasons (May-October); this pattern may be attributed 
to the dilution of rainfall (Fig. 2(e)) and/or the origin of air masses (Fig. 3). The dominant air mass over the continent of China in the dry season could bring highly polluted continental air to Zhanjiang, whereas the dominant air mass from the southerly ocean could bring clean air to the city (Fig. 3). In addition, temporal changes in the relative contributions of different sources could affect nitrogen isotopes, as discussed later.

\section{Influencing Factors of $\delta^{15} \mathrm{~N}-\mathrm{NH}_{4}^{+}$in Precipitation}

The $\delta^{15} \mathrm{~N}-\mathrm{NH}_{4}{ }^{+}$in Zhanjiang was similar to those reported in Guiyang (Xiao et al., 2012) and Guangzhou (Jia and Chen, 2010), but the seasonal distribution pattern is the opposite, exhibiting higher values in the wet seasons and lower values in the dry seasons. This seasonal distribution pattern may be controlled by washout, temperature and sunshine duration (Xiao et al., 2012). If rainfall was the key factor influencing the seasonal patterns, low precipitation during the dry seasons would preferentially wash out heavy ${ }^{15} \mathrm{~N}-\mathrm{NH}_{3}$, then higher $\delta^{15} \mathrm{~N}-\mathrm{NH}_{4}{ }^{+}$occurred in wet deposition. In contrast, complete $\mathrm{NH}_{3}$ removal would result in relatively lower $\delta^{15} \mathrm{~N}_{-} \mathrm{NH}_{4}{ }^{+}$in wet deposition during the wet season than the dry one. In fact, a positive correlation between $\delta^{15} \mathrm{~N}$ $\mathrm{NH}_{4}{ }^{+}$and rainfall was observed in Zhanjiang, and generally high $\delta^{15} \mathrm{~N}-\mathrm{NH}_{4}{ }^{+}$were found during the rainy seasons (Fig. 2). This suggests that the isotopic effect of washout may be less important for $\delta^{15} \mathrm{~N}-\mathrm{NH}_{4}{ }^{+}$in Zhanjiang. Significantly high temperatures were observed during the wet seasons in Zhanjiang. With increasing temperatures, microbial activity will increase and facilitate more ${ }^{14} \mathrm{~N}$-organic matter in the atmosphere to decompose into $\mathrm{NH}_{4}{ }^{+}$, resulting in negative values of $\delta^{15} \mathrm{~N}_{-} \mathrm{NH}_{4}{ }^{+}$(Xie et al., 2008; Xiao et al., 2012). In addition, temperature can increase the volatility of $\mathrm{NH}_{3}$ from sources, leading to lighter $\mathrm{NH}_{3}$ molecules being released into the atmosphere (Sommer et al., 1991; Xiao et al., 2012).
However, higher $\delta^{15} \mathrm{~N}-\mathrm{NH}_{4}{ }^{+}$were found during the wet seasons (higher temperature) in Zhanjiang (Fig. 2). This suggests that temperature was not an important factor controlling seasonal variations of $\delta^{15} \mathrm{~N}^{-\mathrm{NH}_{4}}{ }^{+}$in Zhanjiang. Therefore, sunshine duration is the most likely factor controlling the variations of $\delta^{15} \mathrm{~N}-\mathrm{NH}_{4}{ }^{+}$in precipitation discussed below.

$\mathrm{NH}_{3}$ in the atmosphere is easily absorbed by acidic matter (e.g., $\mathrm{H}_{2} \mathrm{SO}_{4}$ and $\mathrm{HNO}_{3}$; Xiao et al., 2012). A significantly longer sunshine duration provided more photooxidation opportunities and free radicals that produce more sulfur dioxide $\left(\mathrm{SO}_{2}\right)$ and nitrogen oxide $\left(\mathrm{NO}_{x}\right)$ to acidic matter $\left(\mathrm{H}_{2} \mathrm{SO}_{4}\right.$ and $\left.\mathrm{HNO}_{3}\right)$, thereby accelerating the unidirectional conversion of light ${ }^{14} \mathrm{~N}-\mathrm{NH}_{3}$ to $\left(\mathrm{NH}_{4}\right)_{2} \mathrm{SO}_{4}$ and $\mathrm{NH}_{4} \mathrm{NO}_{3}$ (Freyer, 2010; Ottley and Harrison, 1992; Pavuluri et al., 2010). In addition, rain flushing is another way to consume $\mathrm{SO}_{2}$ and $\mathrm{NO}_{x}$. Thus, these reaction processes and heavy rainfall resulted in lower $\mathrm{SO}_{2}$ and $\mathrm{NO}_{x}$ concentrations during the wet seasons. However, rain flushing only occurred in precipitation event, while the reaction processes that produced $\mathrm{SO}_{2}$ and $\mathrm{NO}_{x}$ to acidic matter $\left(\mathrm{H}_{2} \mathrm{SO}_{4}\right.$ and $\left.\mathrm{HNO}_{3}\right)$ occurred at all time. Thus, the reaction process may be the most important way to consume $\mathrm{SO}_{2}$ and $\mathrm{NO}_{x}$. These products by reaction processes are solids, which can be adsorbed and deposited by aerosols. This process results in ${ }^{15} \mathrm{~N}$-enriched residual $\mathrm{NH}_{3}$ in atmosphere. When it rains, rain mainly capture ${ }^{15} \mathrm{~N}$-enriched residual $\mathrm{NH}_{3}$ to produce $\mathrm{NH}_{4}^{+}$(Xiao et al., 2012). We realize that rain can also capture $\mathrm{NH}_{4}^{+}$from $\left(\mathrm{NH}_{4}\right)_{2} \mathrm{SO}_{4}$ and $\mathrm{NH}_{4} \mathrm{NO}_{3}$ in aerosol. However, $\left(\mathrm{NH}_{4}\right)_{2} \mathrm{SO}_{4}$ and $\mathrm{NH}_{4} \mathrm{NO}_{3}$ in aerosol were deposited all the time, thus $\mathrm{NH}_{4}{ }^{+}$in rain sourced from aerosol seems to be less important (Xiao et al., 2012). In addition to the sunshine (photooxidation and free radicals) pathway for the formation of acidic matter, $\mathrm{SO}_{2}$ can be also oxidized by natural transition metal ions to form $\mathrm{H}_{2} \mathrm{SO}_{4}$ (Harris et al., 2013). However, this oxidation pathway by metal ions primarily

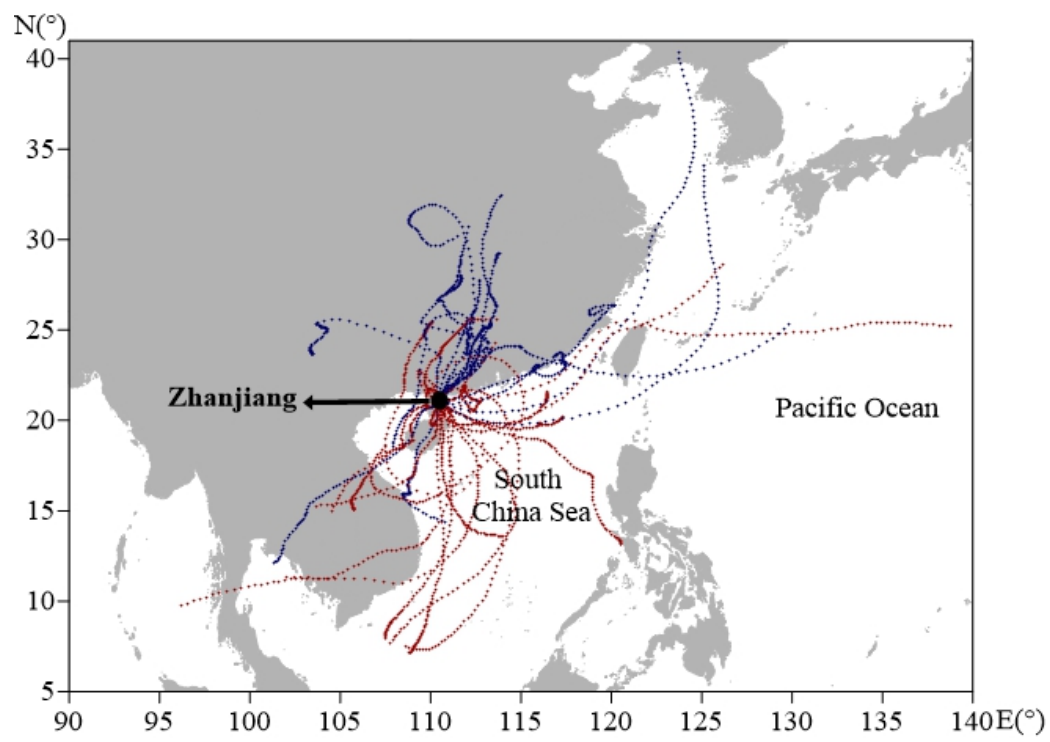

Fig. 3. Backward air mass trajectories in precipitation events in Zhanjiang, based on NOAA HYSPLIT model back trajectories; the red lines denote air mass trajectories occurring in the wet season and the blue lines denote trajectories in the cool dry seasons. (For interpretation of the references to the color in this figure, the reader is referred to the Web version of this article.) 
occur on coarse mineral dust, and the sulfate produced has a short lifetime and little direct or indirect climatic effect (Harris et al., 2013). Thus, this oxidation pathway by metal ions can be less important for the formation of acidic matter. As shown in Fig. 2, there is a significant correlation between sunshine hours and $\delta^{15} \mathrm{~N}-\mathrm{NH}_{4}{ }^{+}$in Zhanjiang, indicating that sunshine duration was indeed the most important factor affecting seasonal variations of $\delta^{15} \mathrm{~N}_{-} \mathrm{NH}_{4}{ }^{+} . \mathrm{SO}_{4}{ }^{2-}$ and $\mathrm{NO}_{3}{ }^{-}$are the most abundant chemical component anion in precipitation (Xiao et al., 2012) and total suspended particulate (TSP; Xiao and Liu, 2004). Thus, the predominant $\mathrm{SO}_{2}$ and $\mathrm{NO}_{x}$ oxidation pathways may be considered as a driver for the trends of $\delta^{15} \mathrm{~N}_{-} \mathrm{NH}_{4}{ }^{+}$. The photooxidation and reaction with free radicals are the main oxidation pathways of $\mathrm{SO}_{2}$ and $\mathrm{NO}_{x}$ in the atmosphere. The rate of photooxidation is about $1 \% \mathrm{SO}_{2} \mathrm{~h}^{-1}$, thus the longer sunshine time would produce more oxidation products. In addition, since the formation of free radicals need sunshine, the high free radicals generally occur in summer and low free radicals occur in winter (Xiao et al., 2012). Due to its low latitude, the sunshine duration of Zhanjiang is relatively longer in the wet season and shorter in the dry season (Fig. 2(a)). In Zhanjiang, due to longer sunshine time in this tropical area, $\mathrm{NO}_{x}$ oxidation via free radical was the predominant pathway (accounting for $87 \%$ in winter and 94\% in summer; Chen et al., 2019). Further $\mathrm{SO}_{2}$ and $\mathrm{NO}_{x}$ oxidized by photooxidation and free radicals in the atmosphere produces more $\mathrm{H}_{2} \mathrm{SO}_{4}$ and $\mathrm{HNO}_{3}$ (Fig. 2(c)). The more $\mathrm{H}_{2} \mathrm{SO}_{4}$ and $\mathrm{HNO}_{3}$ is produced, the more ammonia is absorbed onto $\left(\mathrm{NH}_{4}\right)_{2} \mathrm{SO}_{4}$ and $\mathrm{NH}_{4} \mathrm{NO}_{3}$, which can be deposited by aerosols. The reaction of ammonia with $\mathrm{H}_{2} \mathrm{SO}_{4}$ and $\mathrm{HNO}_{3}$ is a kinetic process (unidirectional reactions) that favors the light isotope of nitrogen in the product, and leads to ${ }^{15} \mathrm{~N}$-enriched residual $\mathrm{NH}_{4}{ }^{+}$in wet deposition (Xiao et al., 2012). Thus, the significantly longer sunshine duration in the wet season and shorter sunshine duration in the dry season may be responsible for the seasonal variations of $\delta^{15} \mathrm{~N}-\mathrm{NH}_{4}^{+}$in Zhanjiang. The pattern of seasonal variation of $\delta^{15} \mathrm{~N}_{-} \mathrm{NH}_{4}{ }^{+}$in Zhanjiang is opposite to the patterns in Guiyang (Xiao et al., 2012) and Guangzhou (Jia and Chen, 2010), where higher $\delta^{15} \mathrm{~N}_{-} \mathrm{NH}_{4}{ }^{+}$occurred in winter and lower values occurred in summer. In contrast to this study, the authors considered temperature to be the most important factor controlling seasonal variations of $\delta^{15} \mathrm{~N}$ $\mathrm{NH}_{4}{ }^{+}$in Guiyang (Xiao et al., 2012) and Guangzhou (Jia and Chen, 2010). This is likely due to shorter sunshine durations in those areas, particularly in Guiyang, which averages only $78 \mathrm{~h} \mathrm{month}^{-1}$ (ranging from 42 to $159 \mathrm{~h} \mathrm{month}^{-1}$ ) of sunshine (Xiao et al., 2012). In contrast, the amount of sunshine in Zhanjiang is significantly greater (average of $150 \mathrm{~h} \mathrm{month}^{-1}$ in 2016 and $154 \mathrm{~h} \mathrm{month}^{-1}$ in 2017). Therefore, we hypothesize that sunshine duration is the most important factor controlling seasonal variations of $\delta^{15} \mathrm{~N}-\mathrm{NH}_{4}{ }^{+}$in precipitation in Zhanjiang, a typical tropical area.

\section{Sources of $\mathrm{NH}_{4}^{+}$in Precipitation}

The $\delta^{15} \mathrm{~N}$ of dominant $\mathrm{NH}_{3}$ emissions are distinct and well characterized as shown in Table 1 . The $\delta^{15} \mathrm{~N}$ in fertilizer and animal waste is relatively low, while $\delta^{15} \mathrm{~N}$ from biomass burning and fossil fuel-derived $\mathrm{NH}_{3}$ are higher (Table 1). As discussed above, isotopic fractionation occurred significantly in the wet seasons due to a longer sunshine duration, suggesting that the $\delta^{15} \mathrm{~N}-\mathrm{NH}_{4}{ }^{+}$values in wet seasons were not suitable to be used in the model to quantify the proportional contribution of the sources. On contrast, isotopic fractionation would be less in the dry seasons due to a shorter sunshine duration. Thus, it is more representative to apply $\delta^{15} \mathrm{~N}-\mathrm{NH}_{4}{ }^{+}$from the dry seasons to identify ammonia sources in Zhanjiang. Here, relative contributions of the sources listed above were estimated in wet deposition using a Bayesian model. Outputs from the SIAR mixing model show that precipitated $\mathrm{NH}_{4}{ }^{+}$ in Zhanjiang originated more from fossil fuel-derived ammonia emissions ( $24 \pm 26 \%$ from vehicle exhaust, $28 \pm 26 \%$ from coal combustion) than from volatilized ammonia emissions $(18 \pm 21 \%$ from animal waste, $19 \pm 20 \%$ from fertilizers $)$ and biomass burning (11 $\pm 5 \%$ ) (Fig. 4). Summarily, the result of our estimation showed that fossil fuel-derived ammonia emissions dominated Zhanjiang (52\%), which was similar to estimates in Guiyang (38\%; Liu et al., 2017). In Guiyang, the depletion of $\delta^{15} \mathrm{~N}-\mathrm{NH}_{4}{ }^{+}$in precipitation for the past decades was attributed to ammonia emissions from domestic waste and sewage (Xiao and Liu, 2002). However, the latest research showed that the ammonia in precipitation in Guiyang was originated from fossil fuel-derived ammonia emission and biomass burning than from domestic waste and sewage and fertilizer (Liu et al., 2017). This is mainly influenced by the increasing human activities. In Zhanjiang, coal is commonly used to generate electricity (Chen et al., 2019). In addition, the dominant air mass over the continent of China during the dry seasons could bring highly polluted continental air to Zhanjiang (Fig. 3). Combustion ammonia sources particularly that from fossil fuels substantially contributed to the observed $\delta^{15} \mathrm{~N}_{-} \mathrm{NH}_{4}{ }^{+}$in precipitation in this tropical city, which should be emphasized in source of anthropogenic ammonia deposition. This suggestion agrees with the bottom-up inventory, which reveals that most $\mathrm{N}$ emissions are derived from coal combustion in China (Fang et al., 2010). Therefore, our results indicate that $\delta^{15} \mathrm{~N}_{-} \mathrm{NH}_{4}{ }^{+}$ in precipitation is more applicable for source identification in dry seasons than in wet seasons in Zhanjiang due to minimal isotope fractionation.

Table 1. The $\delta^{15} \mathrm{~N}$ of $\mathrm{NH}_{3}$ from different sources.

\begin{tabular}{lll}
\hline Sources & $\delta^{15} \mathrm{~N}_{-} \mathrm{NH}_{3}(\%)$ & References \\
\hline Coal combustion & $-8.9 \pm 4.1$ & (Freyer, 1991; Felix et al., 2013) \\
Vehicle exhaust & $-3.4 \pm 1.7$ & (Felix et al., 2013) \\
Biomass burning & $+12.0($ an average) & (Kawashima and Kurahashi, 2011) \\
Animal waste & $-19.0 \pm 14.1$ & (Freyer, 1978; Heaton, 1987; Felix et al., 2013, 2014) \\
Fertilizers & $-26.8 \pm 15.4$ & (Felix et al., 2013, 2014) \\
\hline
\end{tabular}




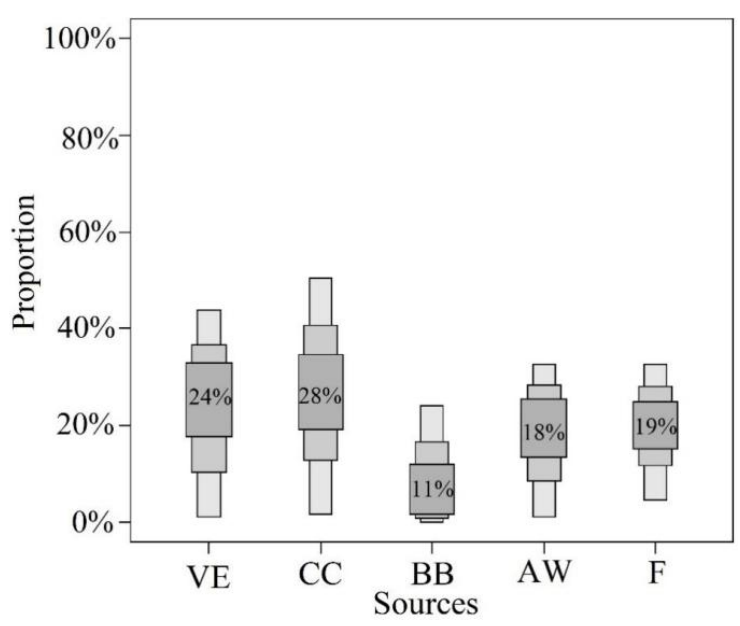

Fig. 4. Percentage contribution of five potential $\mathrm{NH}_{4}^{+}$ sources (VE: vehicle emissions; CC: coal combustion; BB: biomass burning; AW: animal waste; F: fertilizer) for dry season deposition estimates by SIAR.

\section{CONCLUSIONS}

The $\mathrm{NH}_{4}{ }^{+}$and $\delta^{15} \mathrm{~N}_{-} \mathrm{NH}_{4}{ }^{+}$in the wet deposition in Zhanjiang averaged $0.82 \mathrm{mg} \mathrm{L}^{-1}$ and $-9.6 \%$, respectively. The $\mathrm{NH}_{4}^{+}$exhibited higher concentrations during the dry season than the wet one. Comparing the $\delta^{15} \mathrm{~N}_{-} \mathrm{NH}_{4}{ }^{+}$with seasonal patterns of different weather parameters, we found the observed temporal isotopic variation to be primarily caused by the change in sunshine duration. During the wet season, a significantly longer duration increased the opportunities for photooxidation and enhanced the formation of free radicals that produced $\mathrm{H}_{2} \mathrm{SO}_{4}$. This process accelerated the unidirectional conversion of $\mathrm{NH}_{3}$ into $\left(\mathrm{NH}_{4}\right)_{2} \mathrm{SO}_{4}$ - and $\mathrm{NH}_{4} \mathrm{NO}_{3}$-enriched ${ }^{14} \mathrm{~N}$ particles, which can be deposited by aerosols, and resulted in lower atmospheric concentrations of $\mathrm{SO}_{2}$ and $\mathrm{NO}_{2}$ and higher levels of ${ }^{15} \mathrm{~N}$-enriched residual $\mathrm{NH}_{4}{ }^{+}$. By contrast, less isotopic fractionation occurred during the shorter sunshine duration of the dry season, suggesting that $\delta^{15} \mathrm{~N}_{-} \mathrm{NH}_{4}{ }^{+}$in the precipitation should be similar to those of $\mathrm{NH}_{3}$ in the atmosphere and can be applied in source apportionment. A Bayesian model demonstrated that a higher proportion of the concentration of $\mathrm{NH}_{4}^{+}$in Zhanjiang's precipitation was contributed by fossil fuel-derived sources (including vehicle exhaust and coal combustion) than ammonia volatilization and biomass burning.

\section{ACKNOWLEDGEMENTS}

This work was supported by the National Key Research and Development Plan (2016YFC1401403), the National Natural Science Foundation of China (41476066, 41466010, and 41676008), the Guangdong Natural Science Foundation of China (2016A030312004), the International Science and Technology Cooperation Project (GASI-IPOVAI-04), the Fund of Key Laboratory of Global Change and Marine Atmospheric Chemistry (GCMAC1609), and the Project of Enhancing School with Innovation of Guangdong Ocean University (GDOU2016050260).

\section{REFERENCES}

Altieri, K.E., Fawcett, S.E., Peters, A.J., Sigman, D.M. and Hastings, M.G. (2016). Marine biogenic source of atmospheric organic nitrogen in the subtropical North Atlantic. Proc. Natl. Acad. Sci. U.S.A. 113: 925-930.

Altieri, K.E., Hastings, M.G., Peters, A.J., Oleynik, S. and Sigman, D.M. (2015). Isotopic evidence for a marine ammonium source in rainwater at Bermuda. Global Biogeochem. Cycles 28: 1066-1080.

Biswas, M.S., Ghude, S., Gurnale, D., Prabhakaran, T. and Mahajan, A.S. (2019). Simultaneous observations of nitrogen dioxide, formaldehyde and ozone in the IndoGangetic Plain. Aerosol Air Qual. Res. 19: 1749-1764.

Chen, F., Lao, Q., Jia, G., Chen, C., Zhu, Q. and Zhou, X. (2019). Seasonal variations of nitrate dual isotopes in wet deposition in a tropical city in China. Atmos. Environ. 196: 1-9.

Chen, X.Y. and Mulder, J. (2007). Atmospheric deposition of nitrogen at five subtropical forested sites in South China. Sci. Total Environ. 378: 317-330.

Fang, Y.T., Koba, K., Wang, X.M., Wen, D.Z., Li, J., Takebayashi, Y., Liu, X.Y. and Yoh, M. (2010). Anthropogenic imprints on nitrogen and oxygen isotopic composition of precipitation nitrate in a nitrogen-polluted city in southern China. Atmos. Chem. Phys. 10: 13131325.

Felix, J.D., Elliott, E.M., Gish, T.J., Mcconnell, L.L. and Shaw, S.L. (2013). Characterizing the isotopic composition of atmospheric ammonia emission sources using passive samplers and a combined oxidation-bacterial denitrifier approach. Rapid Commun. Mass Spectrom. 27: 2239-2246.

Felix, J.D., Elliott, E.M., Gish, T., Maghirang, R., Cambal, L. and Clougherty, J. (2014). Examining the transport of ammonia emissions across landscapes using nitrogen isotope ratios. Atmos. Environ. 95: 563-570.

Freyer, H.D. (1978). Preliminary ${ }^{15} \mathrm{~N}$ studies on atmospheric nitrogenous trace gases. Pure Appl. Geophys. 116: 393404.

Freyer, H.D. (1991). Seasonal variation of ${ }^{15} \mathrm{~N} /{ }^{14} \mathrm{~N}$ ratios in atmospheric nitrate species. Tellus $B$ 43: 30-44.

Freyer, H.D. (2010). Seasonal trends of $\mathrm{NH}_{4}{ }^{+}$and $\mathrm{NO}_{3}{ }^{-}$ nitrogen isotope composition in rain collected at Jülich, Germany. Tellus 30: 83-92.

Fukuzaki, N. and Hayasaka, H. (2009). Seasonal variations of nitrogen isotopic ratios of ammonium and nitrate in precipitations collected in the Yahiko-Kakuda Mountains Area in Niigata Prefecture, Japan. Water Air Soil Pollut. 203: 391-397.

Galloway, J.N., Dentener, F.J., Capone, D.G., Boyer, E.W., Howarth, R.W., Seitzinger, S.P., Asner, G.P., Cleveland, C.C., Green, P.A. and Holland, E.A. (2004). Nitrogen cycles: Past, present, and future. Biogeochemistry 70: 153-226.

Galloway, J.N., Townsend, A.R., Jan Willem, E., Mateete, B., Zucong, C., Freney, J.R., Martinelli, L.A., Seitzinger, S.P. and Sutton, M.A. (2008). Transformation of the nitrogen cycle: Recent trends, questions, and potential solutions. Science 320: 889-892. 
Harris, E., Sinha, B., van Pinxteren, D., Tilgner, A., Fomba, K.W., Schneider, J., Roth, A., Gnauk, T., Fahlbusch, B., Mertes, S., Lee, T., Collett, J., Foley, S., Borrmann, S., Hoppe, P. and Herrmann, H. (2013). Enhanced role of transition metal ion catalysis during in-cloud oxidation of $\mathrm{SO}_{2}$. Science 340: 727-730.

Heaton, T.H.E. (1987). ${ }^{15} \mathrm{~N} /{ }^{14} \mathrm{~N}$ ratio of nitrate and ammonium in rain at Pretoria, South Africa. Atmos. Environ. 21: 843-852.

Huang, X., Song, Y., Li, M., Li, J., Huo, Q., Cai, X., Zhu, T., Hu, M. and Zhang, H. (2012). A high-resolution ammonia emission inventory in China. Global Biogeochem. Cycles 26: GB1030.

Jia, G. and Chen, F. (2010). Monthly variations in nitrogen isotopes of ammonium and nitrate in wet deposition at Guangzhou, south China. Atmos. Environ. 44: 23092315.

Jiang, F., Liu, F., Lin, Q., Fu, Y., Yang, Y., Peng, L., Lian, X., Zhang, G., Bi, X., Wang, X. and Sheng, G. (2019). Characteristics and formation mechanisms of sulfate and nitrate in size-segregated atmospheric particles from urban Guangzhou, China. Aerosol Air Qual. Res. 19: 1284-1293.

Kang, Y.N., Liu, M.X., Song, Y., Huang, X., Yao, H., Cai, X.H., Zhang, H.S., Kang, L., Liu, X.J., Yan, X.Y., He, H., Zhang, Q., Shao, M. and Zhu, T. (2016). High-resolution ammonia emissions inventories in China from 1980 to 2012. Atmos. Chem. Phys. 16: 2043-2058.

Kawashima, H. and Kurahashi, T. (2011). Inorganic ion and nitrogen isotopic compositions of atmospheric aerosols at Yurihonjo, Japan: Implications for nitrogen sources. Atmos. Environ. 45: 6309-6316.

Li, X., Masuda, H., Koba, K. and Zeng, H. (2007). Nitrogen isotope study on nitrate-contaminated groundwater in the Sichuan Basin, China. Water Air Soil Pollut. 178: 145156.

Lin, Z., Altabet, M.A., Taixing, W. and Ora, H. (2007). Sensitive measurement of $\mathrm{NH}_{4}{ }^{+15} \mathrm{~N} /{ }^{14} \mathrm{~N}\left(\right.$ delta $\left.{ }^{15} \mathrm{NH}_{4}{ }^{+}\right)$at natural abundance levels in fresh and saltwaters. Anal. Chem. 79: 5297-5303.

Liu, X., Zhang, Y., Han, W., Tang, A., Shen, J., Cui, Z., Vitousek, P., Erisman, J.W., Goulding, K. and Christie, P. (2013). Enhanced nitrogen deposition over China. Nature 494: 459-462.

Liu, X.Y., Xiao, H.W., Xiao, H.Y., Song, W., Sun, X.C., Zheng, X.D., Liu, C.Q. and Koba, K. (2017). Stable isotope analyses of precipitation nitrogen sources in Guiyang, southwestern China. Environ. Pollut. 230: 486-494.

Moore, J.W. and Semmens, B.X. (2010). Incorporating uncertainty and prior information into stable isotope mixing models. Ecol. Lett. 11: 470-480.

Ottley, C.J. and Harrison, R.M. (1992). The spatial distribution and particle size of some inorganic nitrogen, sulphur and chlorine species over the North Sea. Atmos. Environ. 26: 1689-1699.

Pavuluri, C.M., Kawamura, K., Tachibana, E. and
Swaminathan, T. (2010). Elevated nitrogen isotope ratios of tropical Indian aerosols from Chennai: Implication for the origins of aerosol nitrogen in South and Southeast Asia. Atmos. Environ. 44: 3597-3604.

Peng, C., Tian, M., Chen, Y., Wang, H., Zhang, L., Shi, G., Liu, Y., Yang, F. and Zhai, C. (2019). Characteristics, formation mechanisms and potential transport pathways of $\mathrm{PM}_{2.5}$ at a rural background site in Chongqing, southwest China. Aerosol Air Qual. Res. 19: 1980-1992.

Sommer, S.G., Olesen, J.E. and Christensen, B.T. (1991). Effects of temperature, wind speed and air humidity on ammonia volatilization from surface applied cattle slurry. J. Agric. Sci. 117: 91-100.

Xiao, H.W., Xiao, H.Y., Long, A.M. and Wang, Y.L. (2012). Who controls the monthly variations of $\mathrm{NH}_{4}^{+}$ nitrogen isotope composition in precipitation? Atmos. Environ. 54: 201-206.

Xiao, H.Y. and Liu, C.Q. (2002). Sources of nitrogen and sulfur in wet deposition at Guiyang, southwest China. Atmos. Environ. 36: 5121-5130.

Xiao, H.Y. and Liu, C.Q. (2004). Chemical characteristics of water-soluble components in TSP over Guiyang, SW China, 2003. Atmos. Environ. 38: 6297-6306.

Xie, Y., Xiong, Z., Xing, G., Yan, X., Shi, S., Sun, G. and Zhu, Z. (2008). Source of nitrogen in wet deposition to a rice agroecosystem at Tai lake region. Atmos. Environ. 42: 5182-5192.

Xu, J., Jiang, H., Zhao, H. and Stephens, B. (2017). Mobile monitoring of personal $\mathrm{NO}_{\mathrm{x}}$ exposures during scripted daily activities in Chicago, IL. Aerosol Air Qual. Res. 17: 1999-2009.

Xue, D., Baets, B.D., Cleemput, O.V., Hennessy, C., Berglund, M. and Boeckx, P. (2012). Use of a Bayesian isotope mixing model to estimate proportional contributions of multiple nitrate sources in surface water. Environ. Pollut. 161: 43-49.

Zhang, M., Zhi, Y., Shi, J. and Wu, L. (2018). Apportionment and uncertainty analysis of nitrate sources based on the dual isotope approach and a Bayesian isotope mixing model at the watershed scale. Sci. Total Environ. 693: 1175-1187.

Zhao, X., Yan, X.Y., Xiong, Z.Q., Xie, Y.X., Xing, G.X., Shi, S.L. and Zhu, Z.L. (2009). Spatial and temporal variation of inorganic nitrogen wet deposition to the Yangtze River Delta Region, China. Water Air Soil Pollut. 203: 277-289.

Zheng, X.D., Liu, X.Y., Song, W., Sun, X.C. and Liu, C.Q. (2018). Nitrogen isotope variations of ammonium across rain events: Implications for different scavenging between ammonia and particulate ammonium. Environ. Pollut. 239: 392-398.

Received for review, June 13, 2019

Revised, March 5, 2020

Accepted, March 19, 2020 